\title{
Multiple Sustainability Dimensions of Retail Sector in Serbia until $2013^{3}$
}

\author{
Article history: \\ Received: 26 September 2015 \\ Sent for revision: 12 October 2015 \\ Received in revised form: 14 December 2015 \\ Accepted: 22 December 2015 \\ Available online: 1 April 2016
}

\begin{abstract}
In this paper, we have analysed the challenges met by the Serbian retail industry in the transition process, its economic and social significance in Serbian economy and society, as well as its environmental performance. Although liquidity and profitability of this sector is insufficient, positive business gains of the whole retail sector after 2007 seems encouraging. Also encouraging is an increasing number of ISO 9001 and 14001 in the trade which may indicate the ecological commitment of the companies. Generally speaking, our research has shown that the retail market in Serbia is on the path to sustainability development, but further improvements are needed. For that purpose, appropriate institutional solutions must be applied.
\end{abstract}

Keywords: sustainability, retail sector, business gains, certification

\section{Održivost maloprodajnog sektora u Srbiji do 2013. godine- višestruki aspekti}

Apstrakt: $U$ ovom radu smo analizirali izazove sa kojima se suočava maloprodajni sektor u Srbiji u toku procesa tranzicije, kao i ekonomskodruštveni značaj i ekološke performanse ovog sektora. Uprkos nedovoljnoj likvidnosti i profitabilnosti, ohrabrujuće deluje pozitivno poslovanje ukupnog maloprodajnog sektora nakon 2007. godine. Takođe, činjenica da se broj ISO 9001 i 14001 sertifikata povećava ohrabruje jer ukazuje na ekološku posvećenost kompanija. Generalno, naše istraživanje je pokazalo da je maloprodajni sektor u Srbiji na putu održivosti, ali da su potrebna dalja

\footnotetext{
${ }^{1}$ University of Novi Sad, Faculty of Economics, Subotica

${ }^{2}$ University of Novi Sad, Faculty of Economics, Subotica, tatjana.brankov@ef.uns.ac.rs

${ }^{3}$ This paper is the result of the research financed by the Ministry of Science and Technological Development: Project number III 46006
} 
Lovre K., Brankov T.: Multiple Sustainability Dimensions of Retail Sector in Serbia...

unapređenja. U tom cilju, neophodno je primeniti odgovarajuća institucionalna rešenja.

Ključne reči: održivost, maloprodajni sektor, poslovni prihodi, sertifikacija

\section{Introduction}

Serbia has experienced one of the most unstable political and economic transitions in Central and Southeastern Europe, among the countries formerly under communist or socialist regime. A number off actors contributed to the Serbian economy of 2000 being half the size it was in 1990 . The civil war, grey economy, an influx of between 800,000 and 1,000,000 refugees from former Yugoslav republics, international economic sanctions, hyperinflation in the period 1992-1994 (the biggest in the world after World War II), which reached its peak in January 1994 at a monthly inflation rate of 313 million percent (Petrović et al., 1999), as well as the damage to Yugoslavia's infrastructure and industry during the 1999 NATO airstrikes.

After the "democratic changes", Serbia renewed its membership in the IMF in December 2000, and gained candidate status for EU membership in March 2012. Serbia has also advanced in negotiations with the WTO, with the country's complete ban on the trade and cultivation of genetically modified products representing the primary remaining obstacle to accession.

The transition process in Serbia moved at a fast pace in the beginning, but slowed down when the country found itself halfway through the reform process. This is partly caused by historical circumstances and partly by differing ideological views. Unlike other countries in CEE, where the private sector immediately became the main bearer of the economic process, in Serbia it did not become the main drive force, even though its growth after the year 2000 is noticeable. One of the reasons of this phenomenon can be seen in the fact that the private sector was already relatively well developed even before the "democratic changes" (Sabic et al., 2012). For example, the authors Dries et al. (2004) describe the Yugoslav retail system as a "decentralized/state-private mixed" system. If we analyze the influx of FDI into Serbia (without which, according to western multilateral institutions, it is impossible to complete a successful "transition" from a centrally planned economy to market economy (Gowan, 1995) we can see the fluctuations in its volume. The average growth rate of total investments was $48 \%$, and the most important influx, according to type of investment, was connected to privatization and capital market (Sabic et al., 2012). For example, the largest influx of FDI was recorded in 2006 (US\$ 5.474 billion) (SIEPA, 2011), thanks to the privatization of the mobile telecommunications operator "Mobtel", purchased by the Norwegian "Telenor". A good example is also the sale of 
The Petroleum Industry of Serbia to the Russian "Gazprom", which took part with $51 \%$ in the total FDI in the transaction year (2009). In the first seven months of 2014, an FDI inflow of EUR 0.7 billion was recorded. The majority of the inflow targets the energy sector (45\% of the total), manufacturing (24\%) and retail trade (7\%). The Gross Domestic Product (GDP) of Serbia was worth 42.52 billion USD in 2013, which makes $0.07 \%$ of the worlds' economy. Following the political changes, GDP per capita rose from 1.152 USD in 2000, to a maximal recorded GDP per capita of 6.465 USD in 2008. As consequence of the global financial crisis, the economy, expressed through GDP growth rate, slipped down by $3.0 \%$ in 2009. After a modest economic recovery in 2011 of $1.6 \%$ of GDP, Serbia fell into recession again in 2012 , with a contraction of $1.7 \%$ of GDP. After a recovery of $3.5 \%$ in 2013 , Serbia's economy moved back into a third recession since 2008 primarily as a result of the May 2014 floods. It is estimated that the floods have had effects equivalent to $2.7 \%$ GDP in damage, and up to $2 \%$ loss in GDP in 2014. The public debt crisis continues to grow, considering that Serbia's total public debt as a share of GDP doubled between 2008 and 2012, reaching $59.6 \%$ of the GDP at the end of 2013. The depressing picture of Serbian economy is reinforced by the large unemployment, the number of actively unemployed persons reached 769,546 at the end of 2013 (Ministry of Finance, 2015). The inflation rate averaged at $7.89 \%$ from 2007 to 2014, as well as stagnant household incomes. According to the Global Food Security Index (GFSI), created by the Economist Intelligence Unit (EIU), the biggest weakness of the food security system in Serbia is the GDP per capita in purchasing power (GFSI, 2012). Comparison of this indicator has shown that Serbia is significantly falling behind in comparison to its EU neighbours (Papic Brankov and Milovanovic, 2014). This is supported by the data that indicates that the total consumption per capita in Serbia, Romania and Bulgaria is three to four times smaller than consumption in the developed CEE countries, such as Slovenia, the Czech Republic and Hungary (International Markets Bureau, 2012). Having the imminent crisis in mind, the government has begun applying new fiscal consolidation measures with the goal of reducing the deficit to under $3 \%$ of the GDP in the year 2017, and halting the public debt growth. The fiscal consolidation resides on three pillars: 1) bringing order to public and state-owned enterprises, 2) reducing unsustainable spending on pensions and public sector salaries, and 3) structural reforms (Fiscal Council, 2014).

2015 is an important year for the Serbian economy as a whole as well as for the retail business sector. Large Croatian company Agrocor entered the Serbian market by the acquisition of a majority shareholding in Mercator.This study does not cover these very complex and new changes, because not enough time passed to draw the clear conclusions. 
Lovre K., Brankov T.: Multiple Sustainability Dimensions of Retail Sector in Serbia...

\section{Retailing globalization and sustainable development}

Retailing globalization has an enormous impact on the market structure in transition and developing countries (Currah and Wrigley, 2004; Wrigley et al., 2005) and it has influenced the development of trade in these countries, their industry and their consumers. The supermarket revolution has imposed its own rules and changed the institutional and organizational food processing system in these countries, thus forcing them to, among other things, adjust their system of standards relating to food quality and safety. It is known, that this kind of change can mostly hurt smaller farmers who are often unable to adapt quickly to the new demands on the food market (Reardon and Berdegué 2002; Dries et al., 2004; Muendo and Tschirley, 2004). On the other hand, if adequate state policy is established, the retail revolution can also bring benefits to small farmers and processors, as well as the end consumers. The small farmers and processors gain access to qualitydifferentiated food markets, which creates possibilities for increasing income, while the benefits for the end consumers lie in potential lowering of food prices (Reardon and Gulati, 2008). In the countries of Central and East Europe (CEE), retail globalization can also be seen as an additional stimulus to improving the competitiveness of local farms, and the finalization of the restructuring of the agri-food chain (Dries et al., 2004). Considering that supermarkets have moved beyond targeting affluent consumers to attending the needs of middle-and low-income consumers (Humphrey, 2007), it is not surprising that the economic difficulties in countries of CEE have not destroyed their popularity. Up to $30 \%$ of 44.3 million shoppers in the 11 monitored CEE countries (Bosnia and Herzegovina, Bulgaria, Croatia, Czech Republic, Hungary, Poland, Romania, Serbia, Slovakia, Slovenia and Ukraine) prefer supermarkets as the main FMCG retail channel (GFK, 2010).

The latest Deloitte analysis of global movements on the retail market shows that the continued weak global economy left retail sector under pressure. Despite softer growth which began decelerating in 2011, profitability for the world's biggest retailers improved. The revenue of the world's top 250 retailers approached US\$4.4 trillion in the fiscal year of 2013. The average size of the Top 250 in 2011, as measured by retail revenue, topped $\$ 17.42$ billion, the composite net profit margin decreased its level at $3.4 \%$ from previous years, and the composite return on assets was 5.3\%- slightly reduced than inprevious period (Deloitte, 2015). Application of the concept of sustainable development, which refers to environmental, social and economic performance, is a trend in modern retail. This concept was studied in many countries, including Serbia. Previous work done by Lukic (2012) had inspired us to carry similar work over a wider period of time. 
Lovre K., Brankov T.: Multiple Sustainability Dimensions of Retail Sector in Serbia...

\section{Research methodology}

In this paper, we have analysed the challenges met by the Serbian retail industry in the transition process, its economic and social significance in Serbian economy and society, as well as its environmental performance. In our research, westarted from the following hypothesis:

1) Serbia is on the path to sustainable development in retailing, but further improvements are needed.

The basic instrument of the research was the method of economic analysis and synthesis. The method of comparative analysis was used as a general method. Data collection was performed by the method of investigation of the sources: Publication of the Serbian institutions- Statistical Office of the Republic of Serbia, Serbian Business Registers Agency, SIEPA, and international institutions- Eurostat and ISO. The approximate timeframe of the analysis of the presented phaenomena varied depending on the data available. Anyway, we had focussed on the period after the world economic crisis.

\section{Research results and discussions}

\subsection{Economic and social aspects of retail}

In order to evaluate the economic impact of retail we have analyzed the impact of trade on the Serbian economy for the period 2008-2012, comparison of the sales in the retail sector in Serbia that relates to CEE countries, income and expenses (2001-2013), as well as retail sector solvency for the period 2007-2013. Social performances of retail sector were analyzed through number of enterprises, the number of employees and turnover as suggested by Lukic (2012).

Table 1 shows trade participation in country worth gross value added (GVA) as well as share in value added at factor cost. Value added of Serbia in 2012 was worth about 25.5 billion EUR (2,889 billion RSD), $11 \%$ of which was the share of distributive trade, or $3.7 \%$ share of retail trade. From the attached table, we can notice a generally negative trend, which started in the year 2008, excluding the participation of retail trade in the value added at factor cost. 
Lovre K., Brankov T.: Multiple Sustainability Dimensions of Retail Sector in Serbia...

Table 1. Trade participation in Serbian economy

\begin{tabular}{|l|l|l|l|l|l|l|}
\hline Gross value added, current prices & Share & 2008 & 2009 & 2010 & 2011 & 2012 \\
\hline Economy of the Republic of Serbia & $\%$ & 100 & 100 & 100 & 100 & 100 \\
\hline $\begin{array}{l}\text { Wholesale and retail trade and repair } \\
\text { of motor vehicles and motorcycles * }\end{array}$ & $\%$ & 12.1 & 11.1 & 10.8 & 10.6 & 11.0 \\
\hline $\begin{array}{l}\text { Retail trade, except motor vehicles and } \\
\text { motorcycles trade* }\end{array}$ & $\%$ & 4.2 & 4.0 & 3.9 & 3.6 & 3.7 \\
\hline Value added at factor costs* & Share & 2008 & 2009 & 2010 & 2011 & 2012 \\
\hline Economy of the Republic of Serbia* & $\%$ & 100 & 100 & 100 & 100 & 100 \\
\hline $\begin{array}{l}\text { Wholesale and retail trade and repair } \\
\text { of motor vehicles and motorcycles * }\end{array}$ & $\%$ & 22.0 & 19.5 & 19.5 & 19.5 & 20.6 \\
\hline $\begin{array}{l}\text { Retail trade, except motor vehicles and } \\
\text { motorcycles trade }\end{array}$ & $\%$ & 3.6 & 4.1 & 4.4 & 4.5 & 4.6 \\
\hline
\end{tabular}

Source: Own calculations based on the Statistical Office of the Republic of Serbia data

Furthermore, our comparison of the participation of the GVA (at basic price) of wholesale and retail trade, transport, accommodation, and food services activities in total NACE activities (Table 2) of Serbia and certain EU countries in the same period (2008-2012) shows that the participation of this sector in the total created value added is smaller in Serbia than it is in the EU 28, Croatia, Greece and Austria.

Table 2. Relative relations of GVA*

\begin{tabular}{|l|c|c|c|c|c|}
\hline \multicolumn{5}{|c|}{ Total, All NACE activities } \\
\hline & 2008 & 2009 & 2010 & 2011 & 2012 \\
\hline EU 28 & 100 & 100 & 100 & 100 & 100 \\
\hline Serbia & 0.24 & 0.23 & 0.21 & 0.23 & 0.21 \\
\hline Croatia & 0.36 & 0.36 & 0.34 & 0.33 & 0.31 \\
\hline Greece & 1.80 & 1.94 & 1.77 & 1.61 & 1.47 \\
\hline Austria & 2.28 & 2.35 & 2.33 & 2.39 & 2.40 \\
\hline GVA, Wholesale and retail trade, transport, accommodation and food services activities \\
\hline EU 28 & 100 & 100 & 100 & 100 & 100 \\
\hline SRB & 0.24 & 0.21 & 0.20 & 0.22 & 0.20 \\
\hline CRO & 0.41 & 0.38 & 0.37 & 0.36 & 0.34 \\
\hline GRC & 2.55 & 2.52 & 2.39 & 2.13 & 1.80 \\
\hline AUST & 2.64 & 2.77 & 2.77 & 2.83 & 2.82 \\
\hline \% of Wholesale and retail trade, transport, accommodation and food services activities \\
in total NACE activities \\
\hline EU 28 & 19.3 & 19.2 & 18.9 & 18.9 & 18.9 \\
\hline SRB & 19.1 & 18.2 & 17.8 & 17.5 & 18.0 \\
\hline CRO & 21.7 & 20.0 & 20.1 & 20.1 & 20.0 \\
\hline GRC & 26.9 & 24.9 & 25.6 & 25.0 & 23.2 \\
\hline AUST & 22.4 & 22.5 & 22.5 & 22.4 & 22.3 \\
\hline
\end{tabular}

Source: Author's calculation based on Eurostat data; ${ }^{*}$ calculated at constant price 
Lovre K., Brankov T.: Multiple Sustainability Dimensions of Retail Sector in Serbia...

In the year 2012, the above named value participation in NACE activities in the neighboring Greece was $23.2 \%$, while it was $5.2 \%$ less in Serbia. The relative relation of GVA of wholesale and retail trade, transport, accommodation, and food services activities in total NACE activities in Serbia and in the EU 28 within the observed timeframe was 0.2:100.

Urbanization in CEE, which brought changes in lifestyle, a growth in income and shifting family structures also resulted in changes in food habits of the population.

Table 3. Sales in retail sector in CEE countries, by country, 2010

\begin{tabular}{|c|c|c|c|}
\hline Country & $\begin{array}{l}\text { Grocery*Retails } \\
\text { Sales Per Capita } \\
\text { (EUR) }\end{array}$ & $\begin{array}{l}\text { Total Food } \\
\text { Spending }{ }^{\star \star} \text { Per } \\
\text { Capita (EUR) }\end{array}$ & $\begin{array}{l}\text { Modern Grocery } \\
\text { Distributor } \\
\text { (MGD) }^{\star \star \star G r o c e r y ~} \\
\text { Sales Per Capita (EUR) }\end{array}$ \\
\hline Albania & 765.35 & 813.70 & 284.43 \\
\hline Armenia & 658.75 & 698.50 & 201.98 \\
\hline Azerbaijan & 723.89 & 772.43 & 192.20 \\
\hline Belarus & 1229.18 & 1311.16 & 403.33 \\
\hline $\begin{array}{l}\text { Bosnia and } \\
\text { Herzegovina }\end{array}$ & 972.78 & 1024.59 & 550.65 \\
\hline Bulgaria & 1065.93 & 1135.91 & 981.85 \\
\hline Croatia & 1816.84 & 1960.24 & 2174.07 \\
\hline $\begin{array}{l}\text { Czech } \\
\text { Republic }\end{array}$ & 1856.67 & 1990.70 & 1710.04 \\
\hline Estonia & 1437.78 & 1546.31 & 1773.59 \\
\hline Georgia & 788.16 & 837.92 & 214.37 \\
\hline Hungary & 1592.95 & 1870.07 & 1382.75 \\
\hline Latvia & 1404.34 & 1479.05 & 1435.85 \\
\hline Lithuania & 1425.26 & 1543.18 & 1228.47 \\
\hline Macedonia & 863.32 & 910.65 & 1104.38 \\
\hline Moldova & 470.95 & 491.66 & 257.13 \\
\hline Montenegro & 1072.81 & 1066.52 & 554.15 \\
\hline Poland & 1616.34 & 1728.18 & 1677.58 \\
\hline Romania & 1150.85 & 1222.38 & 991.18 \\
\hline Russia & 1301.73 & 1377,13 & 680.61 \\
\hline Serbia & 1190.14 & 1255.89 & 801.19 \\
\hline Slovakia & 1385.29 & 1538.50 & 1219.40 \\
\hline Slovenia & 2080.56 & 2391.09 & 2348.65 \\
\hline Ukraine & 641.84 & 694.76 & 353.30 \\
\hline
\end{tabular}

Source: International Markets Bureau (2012). *Refers to all products purchased through a grocery retail establishment, including non-food items **Total food spending includes spending on food services ${ }^{* *} M G D$ refers to modern grocery retailers (largely multiples and chain stores) and cash \& carry/warehouse clubs

After the privatization of the retail sector in CEE in the 1990s and the establishing of the first supermarket chains, this region faced a massive inflow of foreign supermarket chains. The retail sector in CEE countries shifted small 
Lovre K., Brankov T.: Multiple Sustainability Dimensions of Retail Sector in Serbia...

retailers towards larger formats, where foreign companies dominate: Metro Group, Auchan, Globus, Rewe Group, Rautakirja Group, Tesco and Lotte. The biggest retail markets for packaged food and alcoholic beverages are Russia (evaluated at over EUR 100.7 billion in 2011), Poland (EUR 22.2 billion), Ukraine (EUR 21.0 billion in 2011) and the Czech Republic (8.5 billion EUR) (International Markets Bureau, 2012). According to data from the year 2010, presented in Table 3, the average sales (of all products, including food products) in retail chains in CEE was 1190.9 EUR/capita, and the average sales through the network of modern grocery retailers (largely multiples and chain stores) and cash\&carry/warehouse clubs was 979.2 EUR/capita. The average food consumption, including spending on food services per capita in these countries was 1289.6 EUR in 2010. Comparison of this data with the data that relates to Serbia, we can conclude that food consumption per capita in Serbia, as well as the sale of food and non-food products in the retail network is close to the average in the CEE countries. We can also conclude that Serbia falls significantly behind the average in CEE countries when it comes to sale of food and non-food products through networks of modern grocery retailers and cash\&carry/warehouse clubs (801.2 EUR vs. 979.2 EUR) which implies the insufficient development of these formats. Slovenia, a former Yugoslav republic, which has a highly consolidated retail industry (Dmitrović and Bodlaj, 2014) has achieved the undisputed highest sales through modern retail formats (2348.6 EUR/capita).

Table 4. Retail Trade Operating Expanses Coverage with Operating Income in Serbia 2001-2013

\begin{tabular}{|l|c|c|c|}
\hline Year & $\begin{array}{l}\text { Business income } \\
\text { (billion RSD) }\end{array}$ & $\begin{array}{l}\text { Business expenses } \\
\text { (billion RSD) }\end{array}$ & $\begin{array}{l}\text { Coverage of } \\
\text { operating } \\
\text { expenses with } \\
\text { operating } \\
\text { income }\end{array}$ \\
\hline 2001 & 91.5 & 94.2 & $\mathbf{0 . 9 7}$ \\
\hline 2002 & 119.0 & 122.2 & $\mathbf{0 . 9 7}$ \\
\hline 2003 & 133.8 & 137.8 & $\mathbf{0 . 9 7}$ \\
\hline 2004 & 155.6 & 159.5 & $\mathbf{0 . 9 7}$ \\
\hline 2005 & 221.3 & 221.1 & $\mathbf{1 . 0 0}$ \\
\hline 2006 & 281.0 & 282.2 & $\mathbf{0 . 9 9}$ \\
\hline 2007 & 346.2 & 344.1 & $\mathbf{1 . 0 0}$ \\
\hline 2008 & 434.6 & 429.6 & $\mathbf{1 . 0 1}$ \\
\hline 2009 & 466.0 & 461.3 & $\mathbf{1 . 0 1}$ \\
\hline 2010 & 529.5 & 519.6 & $\mathbf{1 . 0 2}$ \\
\hline 2011 & 574.9 & 568.9 & $\mathbf{1 . 0 1}$ \\
\hline 2012 & 631.6 & 621.8 & $\mathbf{1 . 0 2}$ \\
\hline 2013 & 641.6 & 626.6 & $\mathbf{1 . 0 2}$ \\
\hline
\end{tabular}

Source: Serbian Business Registers Agency; *authors calculation 
Lovre K., Brankov T.: Multiple Sustainability Dimensions of Retail Sector in Serbia...

The review of the business gains of the retail sector as a whole, as shown in Table 4, in the Republic of Serbia from 2001-2013 shows that the costeffectiveness of retail trade in Serbia is at a very low level. This sector of economy has done business with losses in four, out of the observed thirteen years. In the other, positive years, the coverage of operating expenses with operating income is almost one the "break even".

The participation of income of the most significant companies in the total income of retail trade in 2013 is shown in Table 5.

Table 5. Companies' participation in the total business income, 2013

\begin{tabular}{|l|c|c|}
\hline Company & $\begin{array}{l}\text { Business } \\
\text { income } \\
\text { (billion } \\
\text { RSD) }\end{array}$ & $\begin{array}{l}\text { Participation in the total } \\
\text { income(\%)* }\end{array}$ \\
\hline DELHAIZE SERBIA DOO BEOGRAD & 76.8 & 11.97 \\
\hline MERCATOR-S DOO NOVI SAD & 63.4 & 9.88 \\
\hline IDEA DOO BEOGRAD & 55.3 & 8.62 \\
\hline METRO CASH \& CARRY DOO & 25.4 & 3.96 \\
\hline BEOGRAD & 17.5 & 2.73 \\
\hline PTP DIS DOO KRNJEVO & 13.8 & 2.15 \\
\hline UNIVEREXPORT DOO NOVI SAD & 7.5 & 1.17 \\
\hline AMAN DOO BEOGRAD, SURČIN & 4.4 & 0.69 \\
\hline VEROPOULOS DOO BEOGRAD & & \\
\hline
\end{tabular}

Source: Serbian Business Registers Agency; *authors calculation

The collective indicators for the solvency class of the retail sector in the last six years (Table 6) point out the poor state of this sector of economy, as well as its insufficient liquidity and profitability. The years lasting trend of a low general liquidity ratio shows that the retail sector must repeatedly run into debt for the purpose of servicing short-term obligations, which leads to further obligations piling up and sharpening the problem of low liquidity. Although the state induced a new measure of shortening the deadline for fulfilling the financial obligations among companies (to a maximum of 60 days) in 2013, this measure did not influence the liquidity of the retail sector. On the contrary, liquidity was reduced in 2013, compared to 2012. The inefficiency of the engaged means can also be noticed through the return on assets rate, which was negative in three observed years. Doing business with loss and a growing debt of the business companies which have been tormenting the Serbian economy for years, have also affected the retail sector, causing reduced participation of own capital in the total financing funds, which reached its lowest value in 2013. 
Lovre K., Brankov T.: Multiple Sustainability Dimensions of Retail Sector in Serbia...

Table 6. The collective indicators for the solvency class of the retail trade sector, 2008-2013

\begin{tabular}{|l|c|c|c|}
\hline Year & Ratio on equity & Current ratio & Return on assets after tax \\
\hline 2008 & 26.9 & 0.83 & $\mathbf{- 2 . 6}$ \\
\hline 2009 & 27.7 & 0.79 & $\mathbf{0 . 3}$ \\
\hline 2010 & 26.9 & 0.82 & $\mathbf{- 0 . 3}$ \\
\hline 2011 & 33.7 & 0.80 & $\mathbf{0 . 8}$ \\
\hline 2012 & 29.0 & 0.84 & $\mathbf{- 0 . 6}$ \\
\hline 2013 & 26.6 & 0.82 & $\mathbf{2 . 3}$ \\
\hline
\end{tabular}

Source: Serbian Business Registers Agency; *authors calculation

Data presented in Table 7 shows that the total number of employed people ${ }^{4}$ in Serbia was around 1.4 million in 2007. Six years later this number decreased by 94.769 or $6.6 \%$. In the same period of time number of employed people in trade fell by 13.804 or $7.1 \%$, while the number of employees in retail trade decreased by $5.1 \%$. This means that the reduction of the number of employees in retail trade is due to the reduction of the total number of employees caused by economic crisis. In the total number of employed trade participated over the period 2007-2013 with approximately $13 \%$. Similarly, the participation of retail sector in it was constantly about $4 \%$ in the observed period of time. For comparison, retail and wholesale contribute very significantly to labor force in the EU, with $13 \%$ of the total number of employees in 2011. Retailing provides 18.6 million jobs in Europe, equivalent to $8.3 \%$ of the total EU workforce ${ }^{5}$. The percentage of national workforce varies among different countries, from $18 \%$ in Greece to $10 \%$ in Finland. This means that participation of trade in Serbia in thetotal number of employees is at the same level as in EU. This is contrary to previous Lukic's research (2012). However, we agree with the previously mentioned research that the percentage of employees in the retail sector in Serbia is significantly lower than in EU (4\% vs. 8.3\%). Retail and wholesale enterprises comprise over $22 \%$ of all active non-financial business activities ${ }^{6}$, while in Serbia their participation is twice higher than in the EU.Within the EU commerce generated $20 \%$ more sales than in manufacturing, three times more than the construction sector and more than seven times than in the information and communications sector ${ }^{2}$. In Serbia, commerce generated 39\% more than in manufacturing, seven times more than theconstruction sector and more than

\footnotetext{
${ }^{4}$ The number of employees in companies, enterprises, institutions, cooperatives and other organizations, including small enterprises

${ }^{5} \mathrm{http}: / /$ www.eurocommerce.eu/media/87967/eurocommerce_study_v2_hd.pdf

${ }^{6}$ The non-financial business economy includes the sectors of industry, construction and distributive trades and services.
} 
Lovre K., Brankov T.: Multiple Sustainability Dimensions of Retail Sector in Serbia...

ten times than in the information sector ${ }^{7}$. This analogy speaks about underdevelopment of the other sectors, not about the development of trade.

Table 7. Employment and turnover in retailing

\begin{tabular}{|l|l|l|l|l|l|l|}
\hline \multicolumn{3}{|c|}{ Enterprises } & \multicolumn{2}{c|}{ Employment } & \multicolumn{2}{c|}{ Turnover } \\
\hline Year & $\begin{array}{l}\text { Number of } \\
\text { enterprises }\end{array}$ & $\begin{array}{l}\text { Share } \\
\%\end{array}$ & $\begin{array}{l}\text { Number of } \\
\text { employees }\end{array}$ & $\begin{array}{l}\text { Share } \\
\%^{*}\end{array}$ & $\begin{array}{l}\text { Total, RSD } \\
\text { million }\end{array}$ & $\begin{array}{l}\text { Share } \\
{ }^{*}\end{array}$ \\
\hline \multicolumn{7}{|c|}{ Economy of the Republic of Serbia } \\
\hline 2007 & 77.464 & 100.0 & 1.432 .851 & 100.0 & 4.965 .046 & 100.0 \\
\hline 2008 & 82.280 & 100.0 & 1.428 .457 & 100.0 & 5.898 .762 & 100.0 \\
\hline 2009 & 82.355 & 100.0 & 1.396 .792 & 100.0 & 5.457 .837 & 100.0 \\
\hline 2010 & 83.787 & 100.0 & 1.354 .637 & 100.0 & 6.303 .515 & 100.0 \\
\hline 2011 & 84.690 & 100.0 & 1.342 .892 & 100.0 & 6.990 .964 & 100.0 \\
\hline 2012 & 84.921 & 100.0 & 1.341 .114 & 100.0 & 7.660 .866 & 100.0 \\
\hline 2013 & 87.529 & 100.0 & 1.338 .082 & 100.0 & 7.886 .415 & 100.0 \\
\hline Wholesale and retail trade and repair of motor vehicles and motorcycles \\
\hline 2007 & 34.205 & 44.1 & 193.841 & 13.5 & 1.916 .714 & 38.6 \\
\hline 2008 & 35.243 & 42.8 & 197.178 & 13.8 & 2.327 .687 & 39.5 \\
\hline 2009 & 34.385 & 41.7 & 190.689 & 13.6 & 2.198 .194 & 40.3 \\
\hline 2010 & 33.860 & 40.4 & 186.748 & 13.8 & 2.486 .012 & 39.4 \\
\hline 2011 & 33.270 & 39.3 & 183.326 & 13.6 & 2.784 .400 & 39.8 \\
\hline 2012 & 32.752 & 38.6 & 183.973 & 13.7 & 3.120 .836 & 40.7 \\
\hline 2013 & 33.554 & 38.3 & 180.037 & 13.4 & 3.014 .988 & 38.2 \\
\hline \multicolumn{7}{|c|}{ Retail trade, except motor vehicles and motorcycles trade } \\
\hline 2007 & 6.059 & 7.8 & 61.727 & 4.3 & 402.269 & 8.1 \\
\hline 2008 & 6.298 & 7.6 & 60.658 & 4.2 & 490.482 & 8.3 \\
\hline 2009 & 6.159 & 7.5 & 58.805 & 4.2 & 485.062 & 8.9 \\
\hline 2010 & 6.171 & 7.4 & 57.434 & 4.2 & 550.259 & 8.7 \\
\hline 2011 & 6.226 & 7.3 & 55.548 & 4.1 & 619.858 & 8.9 \\
\hline 2012 & 6.395 & 7.5 & 58.445 & 4.3 & 696.760 & 9.1 \\
\hline 2013 & 7.005 & 8.0 & 58.545 & 4.4 & 717.145 & 9.1 \\
\hline
\end{tabular}

Source: Serbian Statistical Office; *authors calculation

The indices of turnover in retail trade ${ }^{8}$ are an indicator of a depressing state in the Serbian economy. Ever since the world economic crisis, there has been a trend of continuous reduction of turnover. The total turnover dropped almost $41 \%$ in constant prices in 2013, compared to the year 2008 (Figure 1). A drop in food, drink and tobacco turnover in specialized stores points out not only the low standard, which contributes to a reduced consumption rate of food

\footnotetext{
${ }^{7}$ National statistical Office

${ }^{8}$ The indices of total turnover in current prices, and indices in turnover of food, drink, and tobacco in specialized stores in current prices, $2006=100$, deflator is the consumer price index
} 
Lovre K., Brankov T.: Multiple Sustainability Dimensions of Retail Sector in Serbia...

stores, but also how specialized stores are jeopardized by non-specialized trade formats (hypermarkets, supermarkets, minimarkets), as well as undoubted existence of grey market.

Figure 1. Turnover in retail trade

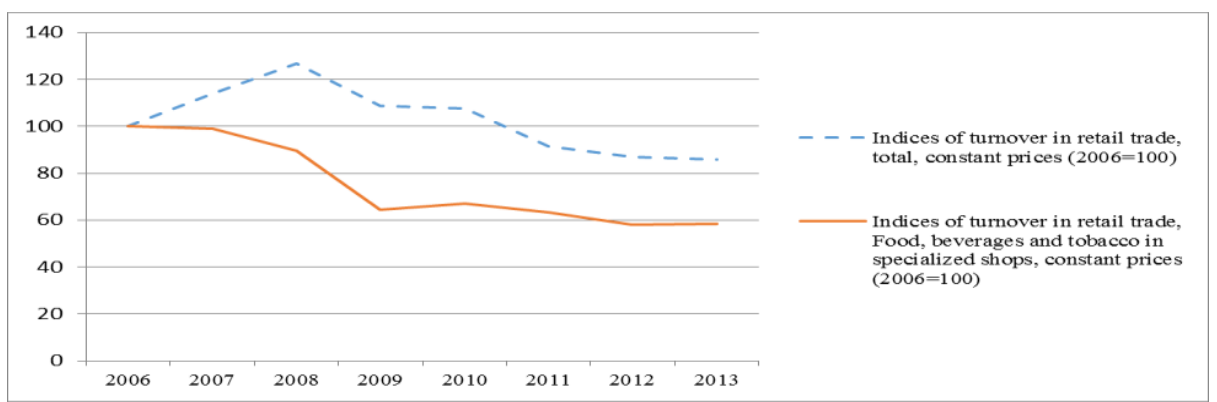

Source: Serbian Statistical Office; *authors calculation

\subsection{Green business in Serbia}

Distributive trade is a very important segment of the Serbian economy if we consider the participation in certified management systems such as ISO 9001 and ISO 14001 in industrial sectors (Table 8). In the reporting five-year period (2009-2015) by participation in the total number of ISO 9001 certificates the trade occupied the first position in three years 2010, 2011 and 2012 with $16.9 \%, 15.9 \%, 16.7 \%$ respectively. In 2009 , the distributive trade accounted for $14.8 \%$, taking up the second position just after the food products, beverage and tobacco (18\%). The worst position (the fourth) was recorded in 2013. The largest share of ISO 9001 certificates went to the basic metal\&fabricated metal products $(13.7 \%)$, followed by the other services $(10.6 \%)$ and the construction (7.7\%). Somewhat worse position of ISO 14001 was recorded. Out of five observed years, only in 2011, with participation of $9 \%$, the distributive trade took up the first position. In 2010 and 2012 with participation of $9.7 \%$ and $11.5 \%$, respectively, it held the second place. During the same period, the construction accounted for the most part $19.7 \%$ in 2010 ; $17 \%$ in 2012). In the last observed year, the distributive trade moved to the seventh position. The largest share of ISO 14001 certificates went to the construction $(13.4 \%)$, followed by basic metal\&fabricated metal products (12.1\%), electrical and optical equipment (8.1\%), other social services $(5.5 \%)$, other services and transport (5.4\%), storage\&communication (5.2\%). By the participation in the total number of certificates, both management systems distributive trade had not fallen under seventh position among thirty-nine industrial sectors in timeframe 2009-2013. 
Lovre K., Brankov T.: Multiple Sustainability Dimensions of Retail Sector in Serbia...

It is encouraging that Green business is increasingly applied by both foreign and domestic retailers and the number of ISO 14001 certificates issued in the trade sector in Serbia is increasing, although with some oscillations. Discouraging isthe participation of Serbia in 2013 in the total world and European number of ISO 14001 certificates, withonly $1.64 \%$ and $4.1 \%$, respectively.

Table 8. Certified distributive trade system in Serbia (2009-2013)

\begin{tabular}{|l|c|c|c|c|c|}
\hline \multicolumn{7}{|c|}{ ISO 14001 } & $\mathbf{2 0 0 9}$ & $\mathbf{2 0 1 0}$ & $\mathbf{2 0 1 1}$ & $\mathbf{2 0 1 2}$ & $\mathbf{2 0 1 3}$ \\
\hline Wholesale\&retail trade, repairs of motor vehicles & 11 & 26 & 44 & 96 & 537 \\
\hline TOTAL- Industrial sectors & 216 & 269 & 489 & 831 & 4950 \\
\hline Participation of the sector in total number & 5.1 & 9.7 & 9.0 & 11.5 & 10.8 \\
\hline \multicolumn{7}{|c|}{ ISO 9001 } & 264 & 210 & 397 & 473 & 1186 \\
\hline Wholesale\&retail trade, repairs of motor vehicles & 1786 & 1240 & 2490 & 2831 & 15933 \\
\hline TOTAL- Industrial sectors & 14.8 & 16.9 & 15.9 & 16.7 & 7.4 \\
\hline Participation of the sector in total number &
\end{tabular}

Source: Authors personal communication with ISO representative

None of the companies in Serbia has a voluntary EU Eco-Management and Audit Scheme (EMAS) certification ${ }^{9}$. Under the project "Law enforcement in the field of industrial pollution control, prevention of chemical accidents and establishing the EMAS system in Serbia" the competent ministry is on the way of creating national program and action plan for EMAS implementation asmechanisms of "EMAS Global" and "EMAS Third Country Registration".According to 2013 Report on economic potentials and activities important for the environment in the Republic of Serbia ${ }^{10}$ cleaner production as a preventive, company-specific environmental protection initiative was introduced in a total of 63 Serbian companies. None of them belong to wholesale\&retail trade sector ${ }^{11}$.

National Ecolabel (flower, a voluntary label promoting environmental excellence) which is in line with EU Ecolabel is awarded 9 times until now (3 in 2010 and 6 more in 2012).

In 2013, there were 258 certified organic producers in Serbia, an increase of 40 producers comparing to $2012^{12}$. In 2013 organic productswere produced on approximately 5.400 ha, out of which 2.500 ha are certified while additional

\footnotetext{
${ }^{9}$ This certification is fully compatible with the requirements of ISO 14001 but does have additional requirements.

${ }_{11}^{10} \mathrm{http}: / /$ www.sepa.gov.rs/download/posebni/Privredne_aktivnosti_2013.pdf

${ }^{11}$ Author'spersonal communicationwith representativesof the Centre forCleaner Production

${ }^{12} \mathrm{http}: / /$ gain.fas.usda.gov/Recent\%20GAIN\%20Publications/Exporter\%20Guide_Belgrade_ Serbia_12-31-2014.pdf
} 
Lovre K., Brankov T.: Multiple Sustainability Dimensions of Retail Sector in Serbia...

2.900 ha are still in the transition process. In other words, expressed in tones, the quantity of produced organic food has been increasing steadily (Table 9 ).

Table 9. Total production in organic agriculture in the Republic of Serbia, in tons

\begin{tabular}{|l|c|c|c|c|}
\hline Crop & $\mathbf{2 0 0 8}$ & $\mathbf{2 0 0 9}$ & $\mathbf{2 0 1 0}$ & $\mathbf{2 0 1 1}$ \\
\hline Maize & 869.5 & 1173 & 1837 & 2226 \\
\hline Wheat & 455 & 578 & 819 & 1333 \\
\hline Soybean & 704 & 984 & 1467.4 & 1475 \\
\hline Apple & 15300 & 22800 & 22610 & 24650 \\
\hline Raspberry & 1755 & 2432 & 2884 & 4012 \\
\hline Strawberry & 302.5 & 441 & 571.5 & 969 \\
\hline Plum & 6150 & 10030 & 11979 & 18450 \\
\hline Sour cherry & 1440 & 1800 & 1350 & 2040 \\
\hline
\end{tabular}

Source: Filipovic (2012)

The retail sector for organic food in Serbia is still underdeveloped. There are only 6 outlets, 4 in Belgrade and 2 in Novi Sad. On the Serbian market most certified organic products are imported, and only some quantities of fresh and processed fruit, vegetables and cereals are of local origin. As from 2013, for the first time, dairy products: fresh milk, yoghurt and sour cream are offered on the market. Although organic products sale has increased in retail in Serbia, average expenditure on organic food per capita issignificantly lower $(5 €)$ than in Croatia or Slovenia (19€) (Lukic, 2012). One of the reasons could be higher prices of organic products as presented in Table 10. So, it can be concluded giving limited incomes and modest living standard that eating organic is not a top priority for anaverage Serbian consumer.

Table 10. Minimum and maximum retail price range for organic and conventional fresh fruits and vegetables at the green markets (January - October 2013)

\begin{tabular}{|l|c|c|c|c|}
\hline Products & \multicolumn{4}{|c|}{ Belgrade } \\
\hline & \multicolumn{2}{|c|}{$\begin{array}{c}\text { Organic products, price } \\
\text { (EUR/kg) }\end{array}$} & \multicolumn{2}{c|}{$\begin{array}{c}\text { Conventional products, price } \\
\text { (EUR/kg) }\end{array}$} \\
\hline & Min & Max & Min & Max \\
\hline Tomatoes & 1.6 & 2.0 & 0.4 & 1.8 \\
\hline Potatoes & 1.1 & 2.4 & 0.3 & 0.7 \\
\hline Onions & 0.7 & 1.5 & 0.3 & 0.9 \\
\hline Apples & 0.9 & 2.5 & 0.2 & 1.3 \\
\hline Apricots & 2.0 & 2.9 & 0.7 & 4.4 \\
\hline
\end{tabular}

Source: http://www.terras.org.rs/ 
Lovre K., Brankov T.: Multiple Sustainability Dimensions of Retail Sector in Serbia...

\section{Conclusion}

Serbia is facing one of the most demanding tasks in the process of economic transition- building a modern market and modern trade. In that sense, we have analysed economic and social significance of the retail industry to Serbian economy and society, as well as its environmental performance. In other words, we wanted to explore sustainability level of retailing.

Retail trade in Serbia plays a significant role in society due to a significant share in the total number of enterprises, employees and total economy turnover. The average food consumption, including spending on food services per capita in Serbia as well as the sale of food and non-food products in the retail network is close to the average in the CEE countries. But, Serbia falls significantly behind the average in CEE countries when it comes to sale of food and non-food products through networks of modern grocery retailers and cash\&carry/warehouse clubs, which implies the insufficient development of these formats.

Since 2008, we can notice a generally negative trend of the retail participation in worth country gross value added, but positive trend regarding the retail participation in the value added at factor cost. Cost-effectiveness of retail trade in Serbia is at a very low level. Also, liquidity and profitability of this sector is insufficient. However, positive business gains of the whole retail sector after 2007 seems encouraging (although the "break even"). Also encouraging is the increasing the number of ISO 9001 and 14001 in the trade, which may indicate the ecological commitment of the companies. In addition, the total organic productions as well as organic market are slowly but progressively rising. This finding confirms our hypothesis "Serbia is on the path to sustainable development in retailing, but further improvements are needed". For that purpose, appropriate institutional solutions must be applied.

Finally, it is important to emphasize that our analysis covers the period until 2013. After that significant changes have taken place in the performance of Serbian economy as well as in operations of the retail sector. These changes have to be subject for future research.

\section{References}

Currah, A., \&Wrigley, N. (2004). Networks of organization learning and adoptionin retail TNCs. Global Network, 4 (1), 1-23.

Deloitte (2015). Global Powers of Retailing 2015 Embracing Innovation. Accessed at www.deloitte.com on October 25, 2015.

Dmitrović, T., \&Bodlaj, M.(2014).Retailing in Slovenia: Current Landscape and 
Lovre K., Brankov T.: Multiple Sustainability Dimensions of Retail Sector in Serbia...

Trends. European Retail Research27, 93-123.

Dries, L., Reardon, T.,\&Swinnen, J.F. (2004). The rapid rise of supermarkets in Central and Eastern Europe: Implications for the agrifood sector and rural development. Development Policy Review, 22(5), 525-556.

Filipovic, V. (2012). Survey on state in organic sector of Republic of Serbia in 2012. In: A. J. Vasile, A.Turek, J. Subic \& D. Dusmanescu (Eds.), Sustainable Technologies, Policies, and Constraints in the Green economy. IGI Global. ISBN 978-1-4666-4098.

Fiscal Council (2014). Fiscal developments in 2014 and basic recommendations for budget revision and medium-term adjustments 2015-2017. Accessed at http://fiskalnisavet.rs/en/ on August 2014.

GFK (2010). Incrises modern retail formats lead in the Central and Eastern Europe. Accessed at http://http://www.retailinfo.cz/system/files/SM_CEE_2010_ press_release_-_MSP_formats_CEE_-_Eng.pdf on August 18, $201 \overline{4}$

Gowan, P. (2005). Neo-Liberal Theory and Practice for Easter Europe. Newleft Review, 213, 3-60.

Humphrey, J. (2007). The supermarket revolution in developing countries: tidal wave or tough competitive struggle? Journal of Economic Geography,7(4), 433-450.

International Markets Bureau (2012). Modern Grocery Retail Trends in Central and Eastern Europe. Market indicator report/ November2012. Accessed at http://www.ats- sea.agr.gc.ca/eur/6293-eng.htm on September14,2014.

Lukić, R. (2012). Sustainable Development of Retail in Serbia. Review of International Comparative Management,13(4), 574-585.

Ministarstvo finansija (2015). Bilten javnih finansija, broj 131. Accesed at http://www.mfin.gov.rs/UserFiles/File/bilten\%20javne\%20finansije/bilten-131web.pdf on October 25, 2015.

Muendo, K. M., \&Tschirley, D., 2004. Improving Kenya's domestic horticultural production and marketing system:current competitiveness, forces of change, and challenges for the future.Working Paper 08A/2004, Nairobi,Tegemeo Institute of Agricultural Policy and Development, Egerton University.

Papic Brankov, T. P., \& Milovanovic, M. (2014). Measuring food (in)security in the Republic of Serbia. Paper presented at the142nd EAAE Seminar, Budapest, May 29-30. Retraived from http://ageconsearch.umn.edu/handle/169093.

Petrović, P., Bogetić, Ž.,\& Vujošević, Z. (1999).TheYugoslav hyperinflation of 19921994: causes, dynamics, and money supply process. Journal of Comparative Economics, 27(2), 335-353.

Reardon, T., \& Berdegué, J.A. (2002). The Rapid Rise of Supermarkets in Latin America: Challenges and Opportunities for Development. Development Policy Review, 20 (4): 317-34.

Reardon, T., \& Gulati, A. (2008). The supermarket revolution in developing countries: Policies for "competitiveness with inclusiveness" Policy briefs 2, International Food Policy Research Institute(IFPRI).

Sabić, D., Vujadinović, S., Milinčić, M., Golić, R., Stojković, S., Joksimović, M.,\& Dimitrijević, D., 2012. The impact of FDI on the transitional economy in Serbia-changes and challenges. Acta Polytechnica Hungarica, 9(3), 65-84.

SIEPA (2011). Investors Profile, Serbia Belgrade. Accessed at http://www.siepa.gov.rs on September 5, 2014.

VanBerkum,S.,\& Bogdanov,N.,(2012).Serbia on the road to EU accession: Consequences for agricultural policy and the agri-food chain. CABI. 
Lovre K., Brankov T.: Multiple Sustainability Dimensions of Retail Sector in Serbia...

Wrigley,N., Coe, N., \& Currah, A. (2005).Globalization retail: conceptualizing the distribution-based transnational corporations (TNC). Progress in Human Geography, 29(4), 437-57. 